\title{
AQUEOUS EXTRACT OF MORINGA (MORINGA OLEIFERA) LEAF (AEMOL) ON THE GROWTH, SENSORY AND HISTOLOGY PARAMETERS OF BROILER CHICKENS
}

\author{
AlABI, O. J. ${ }^{1,3^{*}}-$ NG'AMBI, J. W. ${ }^{2}-$ MBAJIORGU, E. F. ${ }^{4}$ \\ ${ }^{1}$ Research Office, University of Limpopo, Private Bag X1106, Sovenga 0727, South Africa \\ ${ }^{2}$ Department of Agricultural Economics and Animal Production, University of Limpopo, Private \\ Bag X1106, Sovenga 0727, South Africa \\ ${ }^{3}$ Department of Animal Production, Federal University of Technology, P.M.B. 65, Minna, Niger \\ State, Nigeria \\ ${ }^{4}$ Department of Anatomical Science, Faculty of Health Sciences, University of the \\ Witwatersrand Johannesburg, Johannesburg, South Africa \\ *Corresponding author \\ e-mail:alabioj@gmail.com
}

(Received $8^{\text {th }}$ May 2020; accepted $29^{\text {th }}$ Jul 2020)

\begin{abstract}
A completely randomized design experiment was used to determine the effects of aqueous extract of Moringa oleifera leaf (AEMOL) on growth, sensory and histology parameters of broiler chickens. Treatment 1 served as the control (antibiotics), Treatment two was given ordinary water $\left(\mathrm{AEMOL}_{0}\right.$ ). Treatments 3, 4, 5 and 6 contained 30, 60, 90 and $120 \mathrm{ml}$ of AEMOL per litre of water per day, respectively. Data obtained were analyzed using one-way analysis of variance and mean separation was done using Duncan's test for multiple comparisons. Results showed that the extract influenced $(\mathrm{P}<0.05)$ the feed intake and water intake at the broiler starter phase WHILE birds on the control diet had higher values. Finisher phase results showed that final weight, weight gain, feed intake, FCR and water intake were influenced $(\mathrm{P}<0.05)$ by the extract with birds treated with $60 \mathrm{ml} / 1$ of AEMOL doing better for most parameters except the FCR. All the digestibility and sensory parameters measured were also influenced $(\mathrm{P}<0.05)$ by the extract. However, histological parameters measured were not affected $(\mathrm{P}>0.05)$ by the extract. It could be concluded that the extract inclusion levels up to $90 \mathrm{ml} / \mathrm{l}$ can be used to replace antibiotic growth promoter without compromising the advantages of antibiotic growth promoter.
\end{abstract}

Keywords: antibiotics, performance, replace, phytochemical

\section{Introduction}

Broilers are a good source of protein and income to many households and therefore their production attracts the attention of many people. Poultry production remains the most extensive and widely practiced of all livestock enterprises and an important component of socio-cultural and economic development in most countries as well as in food security improvement (Alders, 2005; Dieye et al., 2010). However, the industry in the developing countries is facing some challenges which amongst others include, high feed consumption to gain ratio and high cost of feed due to high prices of feed ingredients (Abbas, 2013). Numerous attempts have been made to overcome these challenges. One of such is the use of antibiotics as growth promoters and to prevent outbreak of diseases (Manyi-Loh et al., 2018), though not without attendant problems such as drug toxicity, residual effects and development of bacterial resistance (Finley et al., 2013). This has led to the ban on the use of antibiotics as growth promoters since 
2006 by the European Union, thereby shifted attention of researchers to safe alternatives such as the use plants/herbs (phytobiotic) in place of antibiotics. Some plants, such as Moringa oleifera, has been found to contain phytonutrients and phytochemicals as secondary metabolites which are physiologically active agents with therapeutic properties as antibiotics. Whereas the human medicinal uses of Moringa oleifera has been studied for many years its use in livestock production has received little attention (Nouman et al., 2013). Recently, research is focusing on its possible use to enhance growth, and nutrient utilization as a livestock fodder crop (Nouman et al., 2013). Incorporation of this herb and its products in livestock feeds and water instead of synthetic products have resulted in more rapid gain, higher production and better feed efficiency (Portugaliza and Fernandez, 2012). Other reports have indicated that Moringa oleifera leaves have potential prebiotic and antioxidant effects (Siddhuraju and Becker, 2003; Teixeira et al., 2014; Alabi et al., 2017). The underlying effects of the bioactive compounds in M. oleifera leaves are believed to induce prebiotic effects, bacterial and immune-stimulant activities (Ghazalah and Ali, 2008) resulting in increased productivity of broiler chickens.

Although there are several studies on the use of Moringa oleifera, however, there are scanty reports on the use of the aqueous Moringa oleifera leaf extract in drinking water to determine its impact on growth performance of broilers in poultry production in Minna, Middle Belt Nigeria. The aqueous extract of Moringa oleifera leaf is readily available, accessible and cost effective for use by the farmers and households. The present study was therefore designed to determine the effect of graded doses of aqueous Moringa oleifera leaf extract on growth performance, sensory and histopathology of broiler chickens and compare such with antibiotic treated broilers.

\section{Materials and methods}

This experiment was conducted at the Teaching and Research Farm of the School of Agriculture and Agricultural Technology, Federal University of Technology, Minna, Niger State. Minna lies within latitude $9^{\circ} 37^{\prime}$ North and longitude $6^{\circ} 32^{\prime}$ East. The average temperature in Minna is between 19 to $37^{\circ} \mathrm{C}$ with an annual rainfall of $1312 \mathrm{~mm}$. The mean annual relative humidity is between 21 and $73 \%$ (Climatetemp, 2016).

\section{Sample preparation}

The leaves of Moringa oleifera were harvested from Minna town and environs. They were air-dried in order to ease pounding and were subsequently ground to powder using a blender. The leaf powder was soaked in water after which the solution was drained using a $1 \mathrm{~mm}$ mesh. The chemical composition of the extract was determined.

\section{Experimental design, treatments and procedures}

A total number of 240-day old Hubbard broiler chickens were purchased from B-not Harel hatchery Ibadan, Nigeria. The birds were kept under intensive management for eight weeks. The birds were randomly allocated to six aqueous extract of Moringa oleifera leaf (AEMOL) treatments. Treatment 1 served as the control (having the antibiotics), while treatment 2 was given ordinary water to serve as AEMOL $_{0}$. Treatments 3, 4, 5 and 6 contained 30, 60, 90 and $120 \mathrm{ml}$ of aqueous extract of Moringa oleifera leaf (AEMOL) per litre per day of water, respectively (Table 1). The treatments 
were replicated four times and each replicate had 10 birds. All necessary management requirements were strictly followed. Throughout the study, feed was given ad-libitum. Each treatment was fed broiler starter diet between day 1 and 21; and broiler finisher diet between days 22 and 56. Water was provided for $20 \mathrm{~h}$ and deprived of water for $4 \mathrm{~h}$ while placed on treatment dosages (so that the birds can take the treatment dosages).

Table 1. Aqueous Moringa oleifera leaf extracts (AEMOL) inclusion levels

\begin{tabular}{c|c}
\hline Treatments & Inclusion level \\
\hline AEMOL $_{0+}$ & Control $\left(\right.$ Gendox $\left.{ }^{\circledR} 1.25 \mathrm{mg} / \mathrm{l}\right)$ \\
AEMOL $_{0}$ & $0 \mathrm{ml} / \mathrm{l}$ \\
AEMOL $_{30}$ & $30 \mathrm{ml} / 1$ \\
AEMOL $_{60}$ & $60 \mathrm{ml} / 1$ \\
AEMOL $_{90}$ & $90 \mathrm{ml} / 1$ \\
AEMOL $_{120}$ & $120 \mathrm{ml} / 1$ \\
\hline
\end{tabular}

\section{Growth performance}

A known quantity of the feed was given to the chickens daily for a period of four weeks with the left over collected every morning (weighed and recorded) throughout the experimental period. The daily feed intake was obtained by subtracting the left-over quantity from the initial quantity offered the previous days. The feed was weighed using weighing balance (RADWAG). The feed conversion ratio (FCR) was calculated as dry matter intake per unit weight gain.

On day 21 , digestibility study was carried out. This involves feeding the animals daily with known quantity of feed. A three-day acclimatization period was allowed prior to a four-day collection period. Droppings voided by each bird were collected on a daily basis at $09.00 \mathrm{am}$. Care was taken to avoid contamination from feathers, scales, debris and feeds. Total faeces voided by each replicate were collected using a collection tray. The faeces was weighed (wet basis) and oven dried at $85^{\circ} \mathrm{C}$ until a constant weight was obtained. At the end of the faecal collection the total dry faeces for each replicate was bulked, mixed and 30\% of it was weighed and ground to a size that could pass through a 2-mm sieve for proximate analysis. The difference between the nutrients in the feed consumed and the faeces or nutrients in the faeces voided multiply by 100 gives the apparent digestibility coefficient of the feed, i.e. FC (feed consumed) - FV (faeces voided) $\mathrm{X} 100=$ apparent digestibility coefficient of the feed.

\section{Sensory evaluation}

Meat samples from the breast meat were taken from two birds randomly selected from each of the replicates of the experimental birds and $5 \mathrm{~g}$ of salt was added to the meat before being subjected to boiling and frying. Samples of meat from each treatment were collected after removing the flesh from the bone (manually), cut into chops of an average weight of $40 \mathrm{~g}$ and labelled for identification. The meat was cooked in a pot with water at a temperature of $65^{\circ} \mathrm{C}$ for $30 \mathrm{~min}$ using a gas cooker as described by Vasanthakumar et al. (1999). Twenty trained panelists were used in the assessment procedure. They were instructed to chew a sample from each treatment. The scoring was based on parameters stated on the scoring sheet: for appearance, juiciness, flavour, tenderness and overall acceptability. Water was served to the panelists to rinse their 
mouth after scoring each sample to reduce flavour carryover. The panelists scored each sample on a nine-point hedonic rating scale adopted from Vasanthakumar et al. (1999).

\section{Histopathology}

After the completion of the experimental period, the histological analysis was carried out at the histology laboratory of the Faculty of Veterinary medicine, Usman Danfodio University, Sokoto, Nigeria. Two birds per replicate were randomly selected, slaughtered, weighed and examined for respiratory tract gross lesions. Both lungs were removed and weighed. Tissue samples of the liver, lungs, kidney, intestine, spleen and heart were taken and fixed in $10 \%$ formalin. The tissues were dehydrated through a graded concentration of ethanol (70,95 and 100\%), cleared in xylene and embedded in paraffin wax. The embedded tissues were stained with hematxylene and eosine for light microscopic examination. Lesions observed were photographed using the Vanox $\mathrm{T}$ Olympus photographing microscope as described by Richard et al. (2008).

Lung weight expressed as a ratio of body weight was called the lung: body weight ratio. The thoracic air sacs were assigned gross lesion scores, where $0=$ clear, $1=$ cloudy, $2=$ cloudy with minimal caseous exudate accumulation and $3=$ severe caseous exudate accumulation. A $2.5-\mathrm{cm}$ longitudinal hemi-sectioned portion of trachea from each chicken was immersion-fixed in a coded container that was three-quarters full of $10 \%$ formalin saline routinely processed, stained with haematoxylin and eosin and examined under light microscope. The severity and distribution of mucosal morphological lesions (loss of cilia, epithelial cell hypertrophy and hyperplasia, inflammation and necrosis) in sections of trachea were recorded. A score was assigned to each lesion and its distribution, which was the sum of $\mathrm{A}+\mathrm{B}$, where A represents the severity of the lesion within the section and $\mathrm{B}$ represents the distribution of the lesion across the section. For injury distribution, scores were either $0=$ no injury, $1=$ focal injury, $2=$ multi focal injury or $3=$ diffuse injury. For each of loss of cilia, epithelial cell hypertrophy/hyperplasia, inflammatory infiltrate and necrosis, a severity score was assigned where $0=$ no cells $(0 \%)$ affected, $1=<25 \%$ of cells affected, $2=25$ to $50 \%$ of cells affected, $3=50$ to $75 \%$ of cells affected and $4=>75 \%$ of cells affected. For inflammation, $0=$ none, $1=$ minimal: if inflammatory cells were directed toward the lumenal epithelium; 2 = mild: if inflammatory cells predominated within the epithelium, and fewer inflammatory cells were found in the lamina propria; $3=$ moderate: if inflammatory cells were found scattered throughout the mucosa; and 4 =marked: if sheets of inflammatory cells filled the mucosa.

\section{Data analysis}

All data obtained were subjected to analysis of variance (ANOVA) for a completely randomized design. Where differences occurred, they were separated using Duncan's new multiple range test (SAS, 2013).

\section{Results}

\section{Proximate and phytochemical composition of Moringa oleifera}

The proximate composition of Moringa oleifera leaf meal analysis is presented in Tables 2 and 3. The dry matter, ether extract, crude protein, crude fibre, ash, and nitrogen free extract contents 
Moringa oleifera leaf meal contained $0.11 \mu \mathrm{g} / \mathrm{ml}$ of total flavonoids, $9.97 \mu \mathrm{g} / \mathrm{ml}$ of total phenols, $0.26 \mathrm{mg} / \mathrm{ml}$ of alkaloids, $1.17 \mu \mathrm{g} / \mathrm{ml}$ of tannins and $245.3 \mu \mathrm{g} / \mathrm{ml}$ of saponins. The aqueous extracts of Moringa oleifera leaf contained $0.11 \mu \mathrm{g} / \mathrm{ml}$ of total flavonoids, $10.78 \mu \mathrm{g} / \mathrm{ml}$ of total phenol, $0.21 \mathrm{mg} / \mathrm{ml}$ of alkaloids, $5.33 \mu \mathrm{g} / \mathrm{ml}$ of tannins and $22.55 \mu \mathrm{g} / \mathrm{ml}$ of saponins. While the aqueous Moringa oleifera residues had $1.22 \mu \mathrm{g} / \mathrm{ml}$ of total flavonoids, $9.70 \mu \mathrm{g} / \mathrm{ml}$ of total phenols, $0.27 \mathrm{mg} / \mathrm{ml}$ of alkaloids, $3.83 \mu \mathrm{g} / \mathrm{ml}$ of tannins and $195.3 \mu \mathrm{g} / \mathrm{ml}$ of saponins.

Table 2. Proximate composition of Moringa oleifera

\begin{tabular}{c|c}
\hline Parameters & Percentage composition (\%) \\
\hline Dry matter & 94.25 \\
Ether extra & 5.50 \\
Crude protein & 23.80 \\
Crude fibre & 16.57 \\
Ash content & 9.75 \\
Nitrogen free extracts & 38.63 \\
\hline
\end{tabular}

Table 3. Phytochemical composition of Moringa oleifera leaf meal, aqueous Moringa oleifera leaf extracts and Moringa oleifera residues

\begin{tabular}{c|c|c|c}
\hline \multirow{2}{*}{ Parameter } & \multicolumn{3}{|c}{ Moringa preparations } \\
\cline { 2 - 4 } & $\begin{array}{c}\text { Ground Moringa } \\
\text { oleifera } \text { leaf meal }\end{array}$ & $\begin{array}{c}\text { Aqueous Moringa } \\
\text { oleifera } \text { leaf extracts }\end{array}$ & $\begin{array}{c}\text { Moring oleifera } \\
\text { residues }\end{array}$ \\
\hline Total flavonoids $(\mu \mathrm{g} / \mathrm{ml})$ & 0.11 & 0.11 & 1.22 \\
Total phenols $(\mu \mathrm{g} / \mathrm{ml})$ & 9.97 & 10.78 & 9.70 \\
Alkaloids $(\mathrm{mg} / \mathrm{ml})$ & 0.26 & 0.21 & 0.27 \\
Tannins $(\mu \mathrm{g} / \mathrm{ml})$ & 1.17 & 5.33 & 3.83 \\
Saponins $(\mu \mathrm{g} / \mathrm{ml})$ & 245.30 & 22.55 & 195.30 \\
\hline
\end{tabular}

\section{Effect of aqueous extract of Moringa oleifera leaf on growth performance of broiler chickens at both starter and finisher phases}

Table 4 shows the results of the effects of aqueous extract of Moringa oleifera leaf on growth performance of broiler chickens during the starter and finisher phases. The initial, final, growth rate, feed conversion ratio and mortality were not influenced $(\mathrm{P}>0.05)$ by AEMOL treatments at the starter phase. However, feed intake and water intake were influenced $(\mathrm{P}<0.05)$ by AEMOL treatments.

Birds on the $\mathrm{AEMOL}_{0}$ treatment had the highest feed intake and was significantly $(P<0.05)$ higher than all other treatments which had similar $(P>0.05)$ feed intake values.

Water intake results showed that birds on control and $\mathrm{AEMOL}_{0}$ treatments had the highest water intake, which were significantly higher $(\mathrm{P}>0.05)$ than those birds on $\mathrm{AEMOL}_{30}$ treatment.

The results of the growth performance at the finisher phase showed that all parameters measured were influenced $(\mathrm{P}<0.05)$ by AEMOL treatments except the initial weight and the water intake which were not affected. Birds on AEMOL $60 \mathrm{ml} / 1$ had highest final weight and feed intake and were significantly $(\mathrm{P}<0.05)$ higher than 
all the other treatments. Similarly, the weight gain results showed that birds on AEMOL $60 \mathrm{ml} / \mathrm{l}$ had significantly $(\mathrm{P}<0.05)$ higher value than all the other treatment except for birds on the control treatment. The feed conversion ratio results showed that birds on the control treatment had the best value and was significantly $(\mathrm{P}<0.05)$ better than all the other treatments.

Table 4. Effect of aqueous extract of Moringa oleifera leaf on performance of Hubbard broiler chickens at both starter and finisher phases

\begin{tabular}{|c|c|c|c|c|c|c|c|}
\hline \multirow{2}{*}{ Parameters } & \multicolumn{6}{|c|}{ Aqueous leaf extract treatments } & \multirow{2}{*}{ SEM } \\
\hline & Control & AEMOL $_{0}$ & AEMOL 30 & AEMOL60 & AEMOL90 & AEMOL $_{120}$ & \\
\hline \multicolumn{7}{|c|}{ Starter phases } & \\
\hline Initial weight (g) & 138.75 & 140.00 & 138.75 & 136.25 & 141.25 & 136.25 & 1.58 \\
\hline Final weight (g) & 1241.25 & 1311.25 & 1242.50 & 1202.50 & 1283.75 & 1300.00 & 23.74 \\
\hline Growth rate $(\mathrm{g})$ & 39.37 & 41.83 & 39.42 & 38.08 & 40.80 & 41.56 & 0.82 \\
\hline Feed intake $(\mathrm{g})$ & $286.76^{\mathrm{b}}$ & $329.69^{a}$ & $289.26^{\mathrm{b}}$ & $283.14^{\mathrm{b}}$ & $286.18^{\mathrm{b}}$ & $280.68^{\mathrm{b}}$ & 4.19 \\
\hline FCR & 0.26 & 0.28 & 0.26 & 0.27 & 0.26 & 0.25 & 0.01 \\
\hline Water intake (ml) & $254.54^{\mathrm{a}}$ & $258.04^{\mathrm{a}}$ & $215.44^{\mathrm{b}}$ & $249.02^{\mathrm{ab}}$ & $245.19^{\mathrm{ab}}$ & $246.14^{\mathrm{ab}}$ & 5.82 \\
\hline \multicolumn{7}{|c|}{ Finisher phases } & \\
\hline Initial weight $(\mathrm{g})$ & 1304.72 & 1264.72 & 1311.95 & 1348.47 & 1387.85 & 1332.78 & 23.74 \\
\hline Final weight (g) & $2350.0^{c}$ & $2242.00^{\mathrm{d}}$ & $2200.00^{\mathrm{e}}$ & $2392.00^{\mathrm{a}}$ & $2367.00^{\mathrm{b}}$ & $2042.00^{\mathrm{f}}$ & 25.28 \\
\hline Weight gain (g) & $1045.3^{\mathrm{a}}$ & $983.95^{\mathrm{b}}$ & $888.05^{c}$ & $1043.5^{\mathrm{a}}$ & $979.15^{\mathrm{b}}$ & $708.98^{\mathrm{d}}$ & 25.04 \\
\hline Feed intake (g) & $3212.47^{\mathrm{bc}}$ & $3082.50^{c}$ & $3300.42^{b}$ & $3549.45^{\mathrm{a}}$ & $3351.29^{\mathrm{b}}$ & $3215.42^{\mathrm{bc}}$ & 7.16 \\
\hline FCR & $3.07^{\mathrm{a}}$ & $3.15^{\mathrm{b}}$ & $3.71^{\mathrm{e}}$ & $3.40^{\mathrm{c}}$ & $3.42^{\mathrm{d}}$ & $4.53^{\mathrm{f}}$ & 0.04 \\
\hline Water intake (ml) & 1304.72 & 1264.72 & 1311.95 & 1348.47 & 1387.85 & 1332.78 & 11.63 \\
\hline
\end{tabular}

a,b,c,d,e,f Means within the same row with different superscripts are significantly different at $\mathrm{P}<0.05$; AEMOL $_{0+}$ contained Gendox ${ }^{\circledR} 1.25 \mathrm{mg} / \mathrm{l}$ of water, AEMOL ${ }_{0}$ contained $0 \mathrm{ml}$ of moringa extract/l of water, $\mathrm{AEMOL}_{30}$ contained $30 \mathrm{ml}$ of moringa extract/l of water, AEMOL 60 contained $60 \mathrm{ml}$ of moringa extract/l of water, AEMOL 90 contained $90 \mathrm{ml}$ of moringa extract/l of water, AEMOL ${ }_{120}$ contained $120 \mathrm{ml}$ of moringa extract/l of water

\section{Effect of aqueous extracts of Moringa oleifera leaf on apparent nutrient digestibility of Hubbard broiler chickens}

Apparent nutrient digestibility results are shown in Table 5. The apparent nutrient digestibility results showed significant difference in all the treatments in the following order of highest to lowest: AEMOL 0 , AEMOL 90, AEMOL $_{60}$, control, AEMOL 120 and AEMOL $_{30}$ respectively. Similar to the dry matter, the crude fibre digestibility differed significantly in all the treatments in the following order of highest to lowest: AEMOL 0 , $\mathrm{AEMOL}_{90}, \mathrm{AEMOL}_{120}, \mathrm{AEMOL}_{30}, \mathrm{AEMOL}_{60}$ and control, respectively.

The ether extract digestibility results showed that the birds on $\mathrm{AEMOL}_{0}$ treatment had the highest digestibility and their values were significantly $(\mathrm{P}<0.05)$ higher than all the other treatments. Birds on $\mathrm{AEMOL}_{30}$ and AEMOL 90 treatments had similar $(P>0.05)$ ether extract values. Similarly, birds on AMOLE 60 and AEMOL $_{120}$ treatments had similar $(\mathrm{P}>0.05)$ ether extract digestibility. Their digestibility values were, however, lower $(\mathrm{P}<0.05)$ than those on $\mathrm{AEMOL}_{30}$ and AEMOL 90 treatments. Bird on the control treatment had the least ether extract digestibility and they were significantly lower $(\mathrm{P}<0.05)$ than all the other treatments. 
The crude protein (CP) digestibility results showed that birds on $\mathrm{AEMOL}_{0}$ and AEMOL $_{60}$ treatments had the highest $\mathrm{CP}$ digestibility and their digestibility were higher $(\mathrm{P}<0.05)$ than the ones in other treatments. Birds on AEMOL ${ }_{90}$ had significantly higher $(\mathrm{P}<0.05) \mathrm{CP}$ digestibility than those on control, $\mathrm{AEMOL}_{120}$ and $\mathrm{AEMOL}_{30}$ which were all significantly different $(\mathrm{P}<0.05)$ from one another.

Birds on $\mathrm{AEMOL}_{0}$ and $\mathrm{AEMOL}_{60}$ had similar $(\mathrm{P}>0.05)$ NFE (nitrogen free ether) digestibility. Their digestibility values were significantly $(\mathrm{P}<0.05)$ lower than those of birds on AEMOL90, control, AEMOL 120 , and AEMOL $_{30}$ treatments, which were significantly $(\mathrm{P}<0.05)$ lower than one another in descending order.

Table 5. Effect of aqueous extract of Moringa oleifera leaf on apparent nutrient digestibility (\%) of Hubbard broiler chickens

\begin{tabular}{c|c|c|c|c|c|c|c}
\hline \multicolumn{8}{c}{ Aqueous leaf extract treatments } \\
\hline Parameters & Control & AEMOL $^{\prime}$ & AEMOL $_{30}$ & AEMOL60 $^{\text {AEMOL }}$ & AEMOL $_{120}$ & SEM \\
Dry matter & $79.17^{\mathrm{d}}$ & $83.57^{\mathrm{a}}$ & $65.94^{\mathrm{f}}$ & $82.69^{\mathrm{c}}$ & $82.88^{\mathrm{b}}$ & $70.92^{\mathrm{e}}$ & 1.43 \\
Crude fibre & $92.43^{\mathrm{f}}$ & $93.66^{\mathrm{a}}$ & $92.85^{\mathrm{d}}$ & $92.59^{\mathrm{e}}$ & $93.20^{\mathrm{b}}$ & $92.97^{\mathrm{c}}$ & 0.13 \\
Ether extract & $98.26^{\mathrm{d}}$ & $98.89^{\mathrm{a}}$ & $98.53^{\mathrm{b}}$ & $98.44^{\mathrm{c}}$ & $98.58^{\mathrm{b}}$ & $98.41^{\mathrm{c}}$ & 0.09 \\
Crude protein & $80.80^{\mathrm{c}}$ & $85.33^{\mathrm{a}}$ & $70.43^{\mathrm{e}}$ & $84.90^{\mathrm{a}}$ & $84.24^{\mathrm{b}}$ & $73.14^{\mathrm{d}}$ & 1.43 \\
Nitrogen free extract & $14.34^{\mathrm{c}}$ & $10.76^{\mathrm{e}}$ & $28.98^{\mathrm{a}}$ & $10.69^{\mathrm{e}}$ & $11.07^{\mathrm{d}}$ & $23.72^{\mathrm{b}}$ & 1.74 \\
\hline
\end{tabular}

a,b,c,de,f Means within the same row with different superscripts are significantly different at $\mathrm{P}<0.05$; AEMOL $_{0+}$ contained Gendox ${ }^{\circledR} 1.25 \mathrm{mg} / 1$ of water, AEMOL ${ }_{0}$ contained $0 \mathrm{ml}$ of moringa extract/l of water, AEMOL 30 contained $30 \mathrm{ml}$ of moringa extract/l of water, AEMOL 60 contained $60 \mathrm{ml}$ of moringa extract/l of water, AEMOL 90 contained $90 \mathrm{ml}$ of moringa extract/l of water, AEMOL ${ }_{120}$ contained $120 \mathrm{ml}$ of moringa extract/l of water

\section{Effect of aqueous extract of Moringa oleifera leaf on sensory evaluation of Hubbard broiler chicken meat}

Presented in Table 6 are the results of the effect of AEMOL treatments on appearance, flavour, juiciness, tenderness and general acceptability. All parameters measured were influenced $(\mathrm{P}<0.05)$ by the treatments.

The meat appearance results showed that birds on the AEMOL $0, \mathrm{AEMOL}_{30}$, and AEMOL $_{60}$ treatments had the best appearance $(\mathrm{P}<0.05)$, but similar $(\mathrm{P}>0.05)$ to meat from birds in $\mathrm{AEMOL}_{0}$ and AEMOL 90 treatments. Likewise, meat from birds on the control, AEMOL 90 and AMOLE $_{120}$ treatments had similar $(\mathrm{P}>0.05)$ appearance. However, the meat from birds on $\mathrm{AEMOL}_{120}$ treatment had least value of appearance.

The results of the meat from birds on AEMOL 0 , control, AEMOL 30 , and AEMOL 60 treatments, their values were similar $(\mathrm{P}>0.05)$ in flavour but those on AEMOL 0 treatment had the best flavour, and were significantly better than those on AMOLE 90 and AEMOL 120 treatments. Meat of birds on control, AEMOL 30, AEMOL $_{60}$, AEMOL 90 treatments had similar $(\mathrm{P}>0.05)$ flavour. Meat juiciness results showed that meat form birds on control, AEMOL $0, \mathrm{AEMOL}_{30}, \mathrm{AEMOL}_{60}$ and AEMOL 90 treatments were similar $(\mathrm{P}>0.05)$ in juiciness values. However, meat of birds from control, AEMOL 30 , treatments and AEMOL 90 had more $(\mathrm{P}<0.05)$ juiciness than those of meat of birds from $\mathrm{AEMOL}_{120}$ treatment.

Meat from birds on the $\mathrm{AMOLE}_{0}$ treatment were more tender $(\mathrm{P}>0.05)$ than those of birds on AEMOL 120 . However, their tenderness value was similar to those of birds from control, AEMOL $30, \mathrm{AEMOL}_{60}$ and AEMOL 90 treatments. 
The general acceptability results showed that meat from birds on AEMOL 0 treatment were better and more acceptable $(\mathrm{P}<0.05)$ than those from other treatments except meat from AEMOL $_{30}$ treatment which had similar values. Birds on control, AEMOL 30, AEMOL $_{60}$ and AEMOL 90 treatments had similar $(\mathrm{P}>0.05)$ acceptability values and they were however significantly more acceptable $(\mathrm{P}<0.05)$ than meat from birds on $\mathrm{AEMOL}_{120}$ treatment.

Table 6. Effect of aqueous extract of Moringa oleifera leaf on sensory evaluation of Hubbard broiler meat

\begin{tabular}{c|c|c|c|c|c|c|c}
\hline \multicolumn{7}{c}{ Aqueous leaf extract treatments } \\
\hline Parameters & Control & AEMOL & AEMOL30 & AEMOL60 & AEMOL90 & AEMOL 120 & SEM \\
Appearance & $7.05^{\mathrm{ab}}$ & $7.60^{\mathrm{a}}$ & $7.35^{\mathrm{a}}$ & $7.45^{\mathrm{a}}$ & $7.10^{\mathrm{ab}}$ & $6.55^{\mathrm{b}}$ & 0.11 \\
Flavour & $7.00^{\mathrm{ab}}$ & $7.50^{\mathrm{a}}$ & $7.25^{\mathrm{ab}}$ & $7.25^{\mathrm{ab}}$ & $6.65^{\mathrm{bc}}$ & $6.16^{\mathrm{c}}$ & 0.11 \\
Juiciness & $6.75^{\mathrm{ab}}$ & $7.45^{\mathrm{a}}$ & $7.15^{\mathrm{a}}$ & $6.65^{\mathrm{ab}}$ & $7.00^{\mathrm{a}}$ & $6.25^{\mathrm{b}}$ & 0.11 \\
Tenderness & $7.20^{\mathrm{ab}}$ & $7.85^{\mathrm{a}}$ & $7.70^{\mathrm{ab}}$ & $6.95^{\mathrm{ab}}$ & $7.15^{\mathrm{abc}}$ & $6.40^{\mathrm{c}}$ & 0.12 \\
General acceptability & $7.25^{\mathrm{b}}$ & $8.30^{\mathrm{a}}$ & $7.65^{\mathrm{ab}}$ & $7.20^{\mathrm{b}}$ & $7.25^{\mathrm{b}}$ & $6.30^{\mathrm{c}}$ & 0.11 \\
\hline
\end{tabular}

a,b,c Means within the same row with different superscripts are significantly different at $\mathrm{P}<0.05$; AEMOL $_{0+}$ contained Gendox ${ }^{\circledR} 1.25 \mathrm{mg} / \mathrm{l}$ of water, AEMOL ${ }_{0}$ contained $0 \mathrm{ml}$ of moringa extract/l of water, $\mathrm{AEMOL}_{30}$ contained $30 \mathrm{ml}$ of moringa extract/l of water, $\mathrm{AEMOL}{ }_{60}$ contained $60 \mathrm{ml}$ of moringa extract/l of water, AEMOL 90 contained $90 \mathrm{ml}$ of moringa extract/l of water, AEMOL ${ }_{120}$ contained $120 \mathrm{ml}$ of moringa extract/l of water

\section{Effect of aqueous extract of Moringa oleifera leaf on histological parameters of Hubbard broiler chickens at finisher phase}

Table 7 shows the effect of aqueous extract of Moringa oleifera leaf on histological parameters of Liver, Lung, Kidney, Intestine, Spleen and Heart of Hubbard broiler chickens. All organs measured showed no sign $(\mathrm{P}>0.05)$ of hypertrophy, hyperplasia, inflammation, necrosis and injury.

\section{Discussion}

The Proximate composition of Moringa oleifera leaf meal analysis results of dry matter (94.25), ether extract (5.50), crude protein (23.80), crude fibre (16.57), ash (9.75), and nitrogen free extract (38.63) in the present study were contrary to the values obtained by Makkar and Becker (1997) who reported the values as $2.15 \%$ of fat content, $27.29 \%$ of crude protein, $10.67 \%$ of crude fibre, $15 \%$ of ash content and $34.08 \%$ N.F.E. These differences in the value may be due to the processing methods, the period of harvesting of the plants and the climatic condition as reported by Fuglie (2001). The results also showed that Moringa oleifera leaf is considerably rich in protein $(23.80 \%)$, crude fiber (16.57\%) which is similar to the findings of Mabruk et al. (2010) and Zaku et al. (2015). However, the dry matter $(94.25 \%)$ and ash $(9.75 \%)$, the fat content $(5.50 \%)$ and nitrogen free extract content $(38.82 \%)$ contents in the present study are similar to those reported obtained by Mabruk et al. (2010) and Ogbe and John (2012).

The results also showed that aqueous processing of Moringa oleifera leaves do not reduce some the phytochemical properties except for saponin which were reduced. Nityanand (1997) and Akinmutimi (2004) observed similar results and reported that most processing methods employed in improving the food value of non-conventional feedstuffs do not eliminate the anti-nutritional factor substances completely. 
Table 7. Effect of aqueous extract of Moringa oleifera leaf on histological parameters of Liver, Lung, Kidney, intestine, spleen and heart of Hubbard broiler chickens

\begin{tabular}{|c|c|c|c|c|c|c|c|}
\hline \multicolumn{8}{|c|}{ Treatments } \\
\hline \multirow{2}{*}{ Organs } & \multirow{2}{*}{ Parameters } & Control & AEMOLo & AMOLE & AMOLE60 & AMOLE90 & AMOLE 120 \\
\hline & & Scores & Scores & Scores & Scores & Scores & Scores \\
\hline Liver & Hypertrophy & None & None & None & None & None & None \\
\hline Liver & Hyperplasia & None & None & None & None & None & None \\
\hline Liver & Inflammation & None & None & None & None & None & None \\
\hline Liver & Necrosis & None & None & None & None & None & None \\
\hline Liver & Injury & None & None & None & None & None & None \\
\hline Lungs & Hypertrophy & None & None & None & None & None & None \\
\hline Lungs & Hyperplasia & None & None & None & None & None & None \\
\hline Lungs & Inflammation & None & None & None & None & None & None \\
\hline Lungs & Necrosis & None & None & None & None & None & None \\
\hline Lungs & Injury & None & None & None & None & None & None \\
\hline Kidney & Hypertrophy & None & None & None & None & None & None \\
\hline Kidney & Hyperplasia & None & None & None & None & None & None \\
\hline Kidney & Inflammation & None & None & None & None & None & None \\
\hline Kidney & Necrosis & None & None & None & None & None & None \\
\hline Kidney & Injury & None & None & None & None & None & None \\
\hline Intestine & Cilia & None & None & None & None & None & None \\
\hline Intestine & Hypertrophy & None & None & None & None & None & None \\
\hline Intestine & Hyperplasia & None & None & None & None & None & None \\
\hline Intestine & Inflammation & None & None & None & None & None & None \\
\hline Intestine & Necrosis & None & None & None & None & None & None \\
\hline Intestine & Injury & None & None & None & None & None & None \\
\hline Spleen & Hypertrophy & None & None & None & None & None & None \\
\hline Spleen & Hyperplasia & None & None & None & None & None & None \\
\hline Spleen & Inflammation & None & None & None & None & None & None \\
\hline Spleen & Necrosis & None & None & None & None & None & None \\
\hline Spleen & Injury & None & None & None & None & None & None \\
\hline Heart & Hypertrophy & None & None & None & None & None & None \\
\hline Heart & Hyperplasia & None & None & None & None & None & None \\
\hline Heart & Inflammation & None & None & None & None & None & None \\
\hline Heart & Necrosis & None & None & None & None & None & None \\
\hline Heart & Injury & None & None & None & None & None & None \\
\hline
\end{tabular}

AEMOL $_{0+}$ contained Gendox ${ }^{\circledR} 1.25 \mathrm{mg} / \mathrm{l}$ of water, AEMOL ${ }_{0}$ contained $0 \mathrm{ml}$ of moringa extract $/ \mathrm{lof}$ water, $\mathrm{AEMOL}_{30}$ contained $30 \mathrm{ml}$ of moringa extract/l of water, AEMOL 60 contained $60 \mathrm{ml}$ of moringa extract/l of water, AEMOL 90 contained $90 \mathrm{ml}$ of moringa extract/l of water, AEMOL ${ }_{120}$ contained $120 \mathrm{ml}$ of moringa extract/l of water

The growth performance results in this study is in agreement with the results reported by Portugaliza and Fernandez (2012) which indicated that AEMOL inclusion levels resulted in lower feed and water intake at the starter phase which is also consistent with less water intake in all AEMOL treated groups compare to control and AEMOL 0 . The reduction in water and feed intake in all AEMOL treated groups compare to control and 
AEMOL $_{0}$, may have translated to reduced growth performance as recorded in the present study. This is consistent with the findings of Portugaliza and Fernandez (2012). This may be due to the presence of antinutrient substance in the extract as reported by Ramchandra et al. (2019). Ramchandra et al. (2019) reported that chemical such as antinutrients substances present in the diet by themselves or their metabolic products arising in the system, reduce feed intake and thus, interfere with the feed utilization. The present results however, are contrast to the report of Oludoyi and Toye (2012) who reported a significant difference in bodyweight at week 4 , between broiler chickens fed diet containing 0, 10 and >15\% MOLM, whereas no significant difference in body weight was observed between pullet groups.

The better final weight, weight gain and feed intake recorded AEMOL60 than in the control group suggests that $60 \mathrm{ml}$ of AEMOL might be an optimal dose of aqueous extract of Moringa oleifera for better broiler growth performance at finisher phase. This is in line with the reports of Kakengi et al. (2003) and Olugbemi et al. (2010) who showed that Moringa oleifera inclusion levels (AEMOL ${ }_{60}$ ) resulted in an increased body weight gain and feed intake due to high protein content in it. On the contrary, birds on aqueous extract of $120 \mathrm{ml}$ per litre of water had the lowest weight gain despite the high protein content in the extract, suggesting an inverse growth relationship- the higher the dose, the higher the antinutrient contents and less the growth possible.

The higher feed intake at the finisher phase compared to the starter phase might be an indication that the older the birds, has better capacity to manage antinutrient contents. The improved FCR of birds on control could be as a result of the low feed intake recorded by the birds on this treatment group.

The results of sensory properties of broiler meat for the different treatments showed significant difference (appearance, flavour, tenderness, juiciness and general acceptance) among the experimental meat samples. No definite trend was in all the parameters assessed. Aqueous extract of Moringa oleifera leaf inclusion levels up to $90 \mathrm{ml} / \mathrm{l}$ were similar in the appearance, flavour, tenderness and general acceptability to control and recorded least flavour for $\mathrm{AEMOL}_{120}$ treated group suggesting that AEMOL inclusion levels up to $90 \mathrm{ml} / \mathrm{l}$ can be used to replace growth promoters in terms of sensory attributes. Additionally, this might mean that poor flavour and tenderness of the meat are produced at inclusion levels above $90 \mathrm{ml} / \mathrm{l}$. The present result is inconsistent with those of Safa et al. (2012) who reported that flavour and juiciness were not significantly influenced by Moringa oleifera leaf meal on broiler chickens.

The results of the histological parameters of tissue samples from the liver, lung, kidney, intestine, spleen, and heart of the broiler chickens did not show any adverse effects of administering aqueous extract of Moringa oleifera leaf to the broiler birds.

\section{Conclusion}

The results of this study showed that aqueous extract of Moringa oleifera leaf inclusion levels up to $60 \mathrm{ml} / \mathrm{l}$ can be used to replace antibiotic growth promoter without compromising the advantages of antibiotic growth promoter. Since it is easily available and can be source cheaply, the use may improve cost effectiveness, reduction in feed consumption with improved growth performance. It is recommended that other methods of extraction could be used to see if higher inclusion level will result in better performance. 


\section{REFERENCES}

[1] Abbas, T. E. (2013): The use of Moringa oleifera in poultry diets. - Turkey Journal of Veterinary Animal Sciences 37: 492-496.

[2] Akinmutimi, A. H. (2004): Evaluation of sword bean (Canavaliagladiata) as an alternative feed resource for broiler chickens. - Ph.D Thesis, Department of Nonruminant Animal Production, Michael Okpara University of Agriculture, Umudike, Nigeria.

[3] Alabi, O. J., Malik, A. D., Ng'ambi, J. W., Obaje, P., Ojo, B. K. (2017): Effect of aqueous Moringa oleifera (Lam) leaf extracts on growth performance and carcass characteristics of hubbard broiler chicken. - Brazilian Journal of Poultry Science 19(2): 273-280.

[4] Alders, R. (2005): L'aviculture: source de profit et de plaisir. - FAO, Rome.

[5] Climatetemp (2016): Minna climate information.

http://www.climatetemp.info/nigeria/minna.html.

[6] Dieye, P. N., Missohou, N. A., Faye, A. (2010): L'aviculture familiale: Un levier pouraméliorer les revenus des éleveurspauvres au Sud du Sénégal. - In: Faye, B., Duteurtre, G. (eds.) L'élevage, richesse des pauvres. Editions Quae, Paris, pp.191-201.

[7] Finley, R. L., Collignon, P., Joakim Larsson, D. G., McEwen, S. A., Xian-Zhi, L., Gaze, W. H., Reid-Smith, R., Timinouni, M., Graham, D. W., Topp, E. (2013): The Scourge of Antibiotic Resistance: The Important Role of the Environment. - Clin. Infect. Dis. 57: 704-710. DOI: $10.1093 / \mathrm{cid} / \mathrm{cit} 355$.

[8] Fuglie, L. J. (2001): Natural Nutrition for the Tropics. - In: Fubalie, L. J. (ed.) The Miracle Tree: The Multiple Attributes of Moringa. CTA Publication, Wageningen, pp. 103-115.

[9] Ghazalah, A. A., Ali, A. M. (2008): Rosemary leaves as dietary supplement for growth broilers. - International Journal of Poultry Science 7(3): 234-239.

[10] Kakengi, A. M. V., Shen, M. N., Sarvert, S. V., Fujihara, T. (2003): Can Moringa oleifera be used as protein supplement to ruminant diet. - Asian Australian Journal of Animal Science 18(1): 42-47.

[11] Mabruk, A. A., Talib, H. N., Mohamed, M. A., Alawad, A. H. (2010): A note on the potential use of moringa oleifera tree as animal feed. - Journal of Veterinary Medicine and Animal Production 1(2)184-188.

[12] Manyi-Loh, C., Mamphweli, S., Meyer, E., Okoh, A. (2018): Antibiotic use in agriculture and its consequential resistance in environmental sources. Potential public health implications. - Molecules (Basel, Switzerland) 23(4): 795. DOI: 10.3390/molecules23040795.

[13] Nityanand, P. (1997): Textbook of Feed Processing Technology. - Vikas Publishing House Pvt. Ltd., New Delhi.

[14] Nouman, W., Basra, S. M. A., Siddiqui, M. T., Yasmeen, A., Gull., T and Alcayde, M. A. C. (2013): Potential of Moringa oleifera L. as livestock fodder crop: a review. - Turkish Journal of Agriculture and Forestry. 38: 1-14.

[15] Ogbe, A. O., John, P. A. (2012): Proximate study, mineral and anti-nutrient composition of Moringa oleifera leaves harvested from Lafia, Nigeria: potential benefits in poultry nutrition and health. - Journal of Microbiology, Biotechnology and Food Sciences 1(3): 296-308.

[16] Oludoyi, I. A., Toye, A. A. (2012): The effect of early feeding of moringa oleifera leaf meal on performance of broiler and pullet chicks. - Agrosearch 12(2): 160-172.

[17] Olugbemi, T. S., Mutayoba, S. K., Lekule, F. P. (2010): Effect of moringa (Moringa oleifera) inclusion in cassava-based diets fed to broiler chickens. - International Journal of Poultry Science 9(4): 363-367. 
[18] Portugaliza, P., Fernandez, T. J. (2012): Growth performance of Cobb broilers given varying concentrations of Malunggay (Moringa oleifera Lam.) aqueous leaf extract. Online Journal of Animal and Feed Research 6(2): 465-469.

[19] Ramchandra, R., Raina, D., Gendley, M. K. (2019): Antinutritional factors in feed and fodder used for livestock and poultry feeding. - Acta Scientific Nutritional Health 3(5): $39-48$.

[20] Richard, J. M., Gavin, C. K., Koh, W., Kamolrat, S (2008): Taking photographs with a microscope. - Am J Trop Med Hyg 79(3): 471-472.

[21] Safa, M. A., El Tazi. (2012): Effect of Feeding different levels of Moringa oleifera leaf meal on the performance and carcass quality of broiler chicks. - International Journal of Science and Research 3(5): 2319-7064.

[22] SAS (2013): Statistical Analysis System. SAS User Guide: Release 9.2. - SAS Institute, Cary NC.

[23] Siddhuraju, P., Becker, K. (2003): Antioxidant properties of various solvent extracts of total phenolic constituents from three different agroclimatic origins of drumstick tree (Moringa oleifera Lam.) leaves. - Journal of Agricultural and Food Chemistry 51(8): 2144-2155.

[24] Teixeira, E., Carvalho, M., Neves, V., Silva, M., Arantes-Pereira, L. (2014): Chemical characteristics and fractionation of proteins from Moringa oleifera Lam. Leaves. - Food Chem. 147(2014): 51-54.

[25] Vasanthakumar, P., Sharma, K., Sastry, V. R. B., Kumar, S. (1999): Effect of graded dietary levels of neem (Azadirachta indica) seed kernel cake on carcass characteristics of broiler rabbits. - Asian-Australasian Journal of Animal Sciences 12(8): 1246-1250.

[26] Zaku, S. G., Emmanuel, S., Tukur, A. A., Kabir, A. (2010): Moringa oleifera an underutilized tree in Nigeria with amazing versatility. - African Journal of Food Science 9(9): 456-461. 